\title{
Rediscovery of the blind-snake Leptotyphlops brasiliensis Laurent, 1949 (Serpentes, Leptotyphlopidae) in the wild
}

\author{
Felipe Curcio ${ }^{1,2}$, Hussam Zaher $^{1}$, and Miguel Trefaut Rodrigues ${ }^{2}$ \\ 1 Museu de Zoologia, Universidade de São Paulo, Caixa Postal 42694, CEP 04299-970, São Paulo, Brazil. E-mails: \\ ffcurcio@yahoo.com; hzaher@ib.usp.br. \\ 2 Universidade de São Paulo, Instituto de Biociências, Departamento de Zoologia, Caixa Postal 11461, CEP $05422-$ \\ 970, São Paulo, Brazil. E-mail: mturodri@usp.br.
}

Keywords: Leptotyphlops brasiliensis, Leptotyphlopidae, Serpentes, rediscovery in the wild, Cerrado, Northeastern Brazil.

According to McDiarmid et al. (1999), 305 species of scolecophidians are presently recognized, with certainly many more undescribed species. Mostly because of their secretive habits, these snakes are difficult to collect in the field. For this reason, scolecophidians are poorly represented in most herpetological collections around the world, and data on their habitat are scarce. However, some blind-snakes may well be common within their distributional range. Leptotyphlops brasiliensis seems to be one of such examples.

This species was described by Laurent (1949), based on a single specimen deposited in the herpetological collection of the Museum de Sciences Naturelles de Belgique (IG 12594) from "Brazil", without further information. The next reference of this species in the literature is due to an error of Cordeiro and Hoge (1974) who misidentified a specimen of $L$. borapeliotes (formerly L. albifrons; Vanzolini 1996) from Sertânia, state of Pernambuco, as L. brasiliensis (Rodrigues and Puorto 1994). This misidentification was first pointed out by Vanzolini et al. (1980), who noted that this

Received 10 December 2002

Accepted 30 December 2002 specimen would have a significantly higher number of dorsal scales (246) than the one present in L. brasiliensis.

Rodrigues and Puorto (1994) presented the only record of this species with a precise locality, ("Barreiras", state of Bahia) and suggested that L. brasiliensis is a typical species from the Cerrado domain. However, no specimens were collected until now to confirm that prediction.

Between February 2000 and January 2001, we conducted an extensive survey of the terrestrial vertebrate fauna of the Estação Ecológica Uruçuí-Una, an area of Cerrado vegetation situated in the southeastern portion of the state of Piauí (Figure 1). The survey is part of an ongoing collaborative program with IBAMA (Instituto Nacional do Meio Ambiente e Recursos Renováveis), in an effort to sample faunal representatives of the transitional area between Caatinga and Cerrado biomes, typical of the state of Piauí. As a result of the survey, we collected four new specimens of $L$. brasiliensis in one of our pit-fall traps stations located on the top of an extensive plateau covered exclusively with Cerrado vegetation. One of the specimens was photographed (Figure 2). 


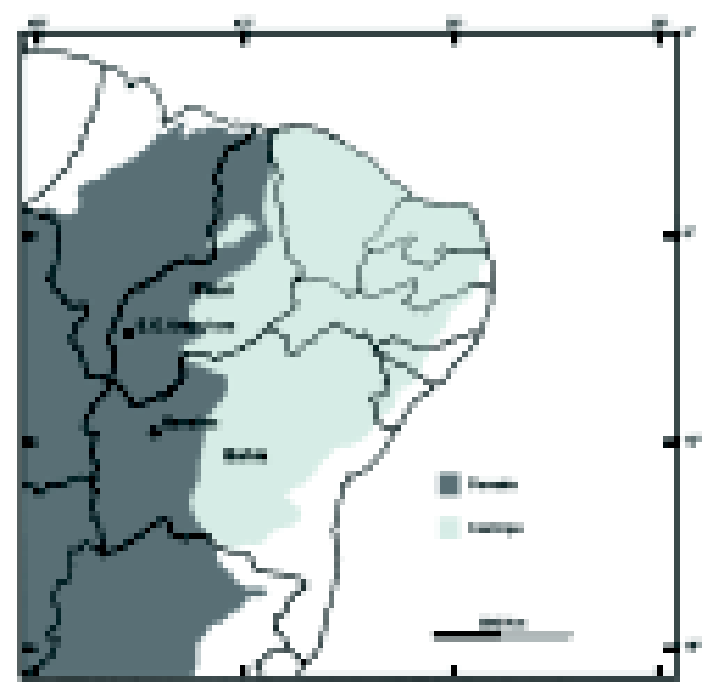

Figure 1 - Geographical map of Northeastern Brazil with relevant localities plotted. Estação Ecológica Uruçuí-Una is situated in the southeastern portion of the state of Piauí whereas the city of Barreiras is located in the northwestern portion of the state of Bahia. Both localities are near the area of ecological tension between Cerrado (dark grey) and Caatinga (light grey).

The reserve consists of high and lowland areas resulting from the dissection of relictual arenitic plateaus. The lowland part of the reserve is covered by typical Cerrado vegetation, either on rocky or sandy soils, interrupted along drainages by gallery forests. Gallery forests are absent from the plateau (Chapada), where the Cerrado is continuous and better preserved than on low altitudinal areas, growing only on sandy soils. Our total survey effort in the area along three field campaigns (February-March 2000 / July 2000 / January-February 2001) was equivalent to 2,080 pit-fall.day. Collecting effort was significantly more intensive in the lowland areas than in the plateau (respectively, 180 and 1,900 pit-fall.day), but L. brasiliensis was only found in the highlands. However, the lowlands of the Reserve are highly degraded by local population, who set fire to extensive areas of

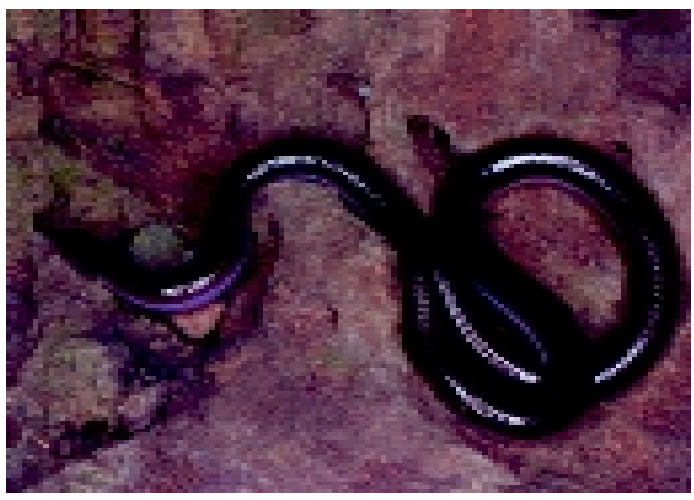

Figure 2 - Leptotyphlops brasiliensis from Estação Ecológica Uruçuí-Una, Piauí, Northeastern Brazil.

Cerrado vegetation every year for plantation and grazing fields. Such activities may contribute to the drastic populational decline of several reptiles, including $L$. brasiliensis.

Our specimens agree in most aspects with the specimen described by Rodrigues and Puorto (1994) which are diagnosed by the absence of a distinct supraocular scale, the number of dorsal (193-210) and circumcaudal (10) scales, and a colour pattern consisting of uniform brown dorsum and flanks and a creamy white venter (Figure 2). Nevertheless it is worth to note that the number (3), and relative size of supralabial scales is the same as for the specimen of Barreiras, described by Rodrigues and Puorto (1994), contrasting with the two supralabial scales present in the holotype of L. brasiliensis and illustrated by Laurent (1949), confirmed by inspection of photographs of the type. As in the Barreira's specimen, our specimens retain a small and low first supralabial scale whereas the second one is high and narrow. However, the first scale lacks a rounded, convex anterior border in all four specimens, in contrast with the specimen illustrated by Rodrigues and Puorto (1994). The distinct pattern of supralabial scales present in the holotype on the one hand, and our specimens on the other hand, is puzzling. However, such variation does not 
Table 1 - Measurements and scale counts of all known specimens of Leptotyphlops brasiliensis. TTL, total length; TL, tail length; DS, number of dorsals; SS, number of subcaudals; SL, number of supralabials; IL, number of infralabials; MD, mid-body diameter.

\begin{tabular}{ccccccccc}
\hline & TTL $(\mathbf{m m})$ & TL $(\mathbf{m m})$ & DS & SS & SL & IL & MD (mm) & SEX \\
\hline MZUSP 12190 & 184 & 15 & 197 & 19 & 3 & 4 & 3.87 & male \\
MZUSP 12189 & 203 & 17 & 193 & 18 & 3 & 4 & 5.14 & male \\
MZUSP 12192 & 170 & 12 & 202 & 17 & 3 & 4 & 4.00 & female \\
MZUSP 12191 & 143 & 12 & 194 & 19 & 3 & 4 & 3.84 & female \\
IG 12594 & $?$ & $?$ & 207 & 16 & 2 & 4 & $?$ & $?$ \\
IB 50436 & 248 & 17 & 210 & 15 & 3 & 4 & $?$ & $?$ \\
\hline
\end{tabular}

represent, in our view, compelling evidence that these are distinct taxa but rather that the species shows intraspecific variation on the number of supralabial scales. It is, nevertheless, impossible to ascertain whether there have been loss or fusion of supralabial scales on the type specimen. This assumption still needs to be tested against broader samples.

Measurements and scale counts of all known specimens are presented in Table 1 (numbers for the holotype are reported as in the original description). Males have longer tails than females, a widespread condition in snakes. However, such putative sexual dimorphism in tail length still needs to be confirmed against larger samples.

Although the Reserve is situated near the area of extensive contact between Cerrado and Caatinga (Figure 1), the discovery of $L$. brasiliensis in this locality corroborates the previous suggestion that this species is associated with the Cerrado formation. The absence of this snake from other areas of Cerrado intensively surveyed, particularly in central Brazil (Nogueira 2001, Valdujo and Nogueira 2001), suggests that L. brasiliensis could be restricted to a more northern distribution within the Cerrado. More intensive surveys are needed in order to clarify such issues.

\section{Acknowledgements}

The authors are grateful to Deocleciano Guedes, head of the IBAMA's Regional Office of the state of Piauí, for his constant support, and to our field companions for their invaluable help. We also thank Georges Lenglet, Curator of Vertebrates of the Institut Royal des Sciences Naturelles de Belgique, who kindly made available digital photographs of the holotype. The present study was supported by a grant from the Fundação O Boticário para a Preservação da Natureza, and by the Instituto Brasileiro do Meio Ambiente e Recursos Naturais Renováveis (IBAMA). FC is supported by grant no. 132639/2001-7 from the Conselho Nacional de Desenvolvimento Científico e Tecnológico (CNPq). Thanks are also due to Fundação de Amparo à Pesquisa do Estado de São Paulo (FAPESP).

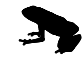

\section{References}

Cordeiro, C. L. and A. R. Hoge. 1974. Contribuição ao conhecimento das serpentes do Estado de Pernambuco. Memórias do Instituto Butantan 37: 261-290.

Laurent, R. 1949. Notes sur quelques reptiles appartenant à la collection de 1'Institut Royal des Sciences Naturelles de Belgique. III. Formes américaines. 
Bulletin de l'Institut Royal des Sciences Naturelles de Belgique 25: 1-20.

McDiarmid, R. W., J. A. Campbell, and T. A. Touré. 1999. Snake Species of the World. A taxonomic and geographic reference. Vol. 1. Washington. The Herpetologists' League. 511 pp.

Nogueira, C. 2001. New records of squamate reptiles in Central Brazilian Cerrado II: Brasília region. Herpetological Review 32: 285-287.

Rodrigues, M. T. and G. Puorto. 1994. On the second specimen of Leptotyphlops brasiliensis Laurent, 1949 (Serpentes, Leptotyphlopidae). Journal of Herpetology 28: 393-394.
Valdujo, P. H. and C. Nogueira. New records of squamate reptiles in Central Brazilian Cerrado: Emas National Park region. Herpetological Review 32: 128-130.

Vanzolini, P. E. 1996. A new (and very old) species of Leptotyphlops from Northeastern Brasil (Serpentes, Leptotyphlopidae). Papéis Avulsos de Zoologia, São Paulo 39: 281-291.

Vanzolini, P. E., A. M. M. Ramos-Costa, and L. J. Vitt. 1980. Répteis das Caatingas. Rio de Janeiro. Academia Brasileira de Ciências. 161pp. 